\title{
De-Constructing Decentralization and Devolution of Powers: Rethinking the Functionality of Local Government System in Nigeria.
}

\author{
Jude Odigbo \\ Department of Political Science \\ Federal University Wukari, Nigeria.
}

\begin{abstract}
The paper seeks to examine the functioning of local government as a tier of government in Nigeria in the present struggle by state governments to apparently stultify the existence of democratic governance at the local level and assume total control of local councils in Nigeria. This paper situates poor performance of the fourth republic local government system in Nigeria in the present trend of dismantling democratic structures at the local level and usurping the constitutional responsibilities of the local government by the state. It is the view of the paper that for the local governments in Nigeria to perform optimally, the excesses of the state governments would be checked. This in the opinion of this paper demands clearing constitutional clouds and incongruences that fraught the 1999 constitution and ensuring commensurate autonomy that would guarantee autonomous but co-ordinated local government system in Nigeria. The paper adopts democratic-participatory theory and uses qualitative method of analysis as its methodological approach. It recommends that the legislature should expedite action in the light of the present constitutional amendment to end undemocratic practices at the local level before local governments in Nigeria fully become subsidiary agencies of the state governors.
\end{abstract}

Key words: Decentralization, Devolution, Functionality, Local Government, Nigeria.

\section{Introduction}

The local government system is globally considered to be inextricably essential because it offers participatory opportunity to people especially at the grassroots and serves as a veritable administrative structure for training future leaders. Its proximity to the rural dwellers positions the local government aptly in identifying challenges facing people at the community level and as well developing viable strategies to solving these problems. It is in this regard that Ezeani (2004:24) rightly noted that local government system is generally seen as a veritable agent of development and grassroot participation in the democratic process. The strength of local governance lies on its representation of community values, ideas and solving community problems which underlie its existence. The objectives of the devolution of responsibility - and the powers that correspond - as part of a strategy of local governance were multiple and included the establishment of a pan-territorial presence, the cultivation of legitimacy, and the generation of consent (Olukoshi 2011:3).

In Nigeria, the emergence of local administration during colonial rule seems to be fundamentally introduced to replace the existing native authority structure with the main aim of providing administrative convenience for the colonist and reducing cost of administration, facilitate representative government. The representative local government emanated from 1947 colonial secretary directive that indirect rule of native authority be replaced with representative governments in line with request from African intelligentia (Ojah, 2005:95). Since then, local government system in Nigeria has evolved several stages in an effort to ensuring efficiency and effective local government that would respond to local needs. These stages especially during colonialism recorded several political bruises. Some of the better known episodes include the Satiru uprising, the Egba protests, and the Aba Women's "riot" (Olukoshi 2011:3). The post-independent era appears to be marred with contestation and confrontations on constitutional legality of control and the existence of local government system in Nigeria. This could largely be attributed to constitutional "clouds" surrounding its establishment.

However, these contestations and confrontations appeared to have necessitated the introduction of reforms to better position local administration for effectiveness and a tier of government that could function within the ambit of the law without or less uncertainty. As a result, many commissions have been initiated in the past by federal government towards ensuring a reform that will enhance local governance. The impacts of these reforms such as 1976 local government reform, the 1984/5 reform, otherwise known as Dasuki led review committee, the 1989 technical committee on civil service reform and the 2003 Sanda Ndayako commission on 
local government are well documented (see Gboyega 1987; Mukoro 2003; Ikeanyibe 2009; Omotola 2009; Nwanegbo 2007; Nwanegbo and Chikendu 2005; Nwanegbo and Okafor 2005; Adedokun 2004).

Over five decades since Nigeria's independence, corruption, poor governance, inadequate staffing, deplorable structures, contestation on the nature, existence and control of local government remained major principles underpinning local governance in Nigeria. In spite of numerous reforms towards containing or addressing critical aspects of its development, local government system seems to be the most crawling tier of government in Nigeria. The role and place of local administration in the overall architecture of post-colonial governance has been marked by twists and turns that could be said to comprise an admixture of progress and regression (Olukoshi 2011:4). In fact, the present trend of subverting its existence appears to portray local councils as field administrative unit. It diminishes its relevance and suffocates rural development. Also important is the distinct desperate tendency of governors of various states to assume total control of local government. These tendencies seem to be rooted in the constitutional contraptions gnawing the existence of local government which appear to have provided fertile political ground for state governments to completely eclipsed the supposedly third tier of government in Nigeria. It is against this background that this study seeks to interrogate the functionality of local government system in Nigeria bearing in mind constitutional deficiencies of its establishment and the present trend of dismantling local councils in preference to care-taker committees by states in an effort to exercise total control of the affairs of the local government in Nigeria.

\section{Decentralization, Devolution And The Local Government: Conceptual And Theoretical Discourses.}

The concept of decentralization, devolution appears to be central in the debate for the establishment of effective and efficient local government. This is because these concepts provided adequate directional focus for development of local council, define its duties, responsibilities, patterns and relations with other tiers of governments. The quest to expand government in such a way that it touches all, provides greatest happiness to greatest number of citizens necessitated the evolution of modern local government system. It thus, could be asserted that decentralization brought new challenges, responsibilities to local councils, especially within the context of training and provision of good governance. In spite of form or method decentralization takes place, the essence is to ensure transfer of authority to satiate needs at different sectors or levels of administration. For Rondinelli (1981:137):

\section{decentralization is defined as the transfer or delegation of legal and political authority to plan, make decisions and manage public functions from the central government and its agencies to field organizations of those agencies, subordinate units of government, semi-autonomous public corporations, area wide, or regional development authorities; functional authorities, autonomous local governments, or non- governmental organizations.}

In the same vein, Tötemeyer (1999:108) contends that decentralization entails a process of dividing and distributing authority, power and responsibility for programmes and policy implementation to subunits, as well as reassigning decision-making responsibilities to lower governmental units on a geographical basis. In fact, it could be asserted that such authority distribution enhances "localization" of governance. This helps to foster peaceful co-existence in the polity especially at the local level, provides conducive relationship between the rulers and the ruled and instilled "we" feeling that serves as catalyst for development. A relationship that would maintain stability, present development agenda from the perspective of collective communal effort and transparently enhance leadership. Indeed, explaining the invaluable contribution of the concept of decentralization to the establishment and operation of local administration, Manhood cited in Dalhatu (2006), observed that "too much concentration of political and economic power at one level would ultimately and inevitably lead to what he referred to as managerial constipation"(see Asaju 2010:100). In this direction he posits that decentralization depicts:

an arrangement by which the management of the public affairs of a
country is shared by the central/ state/province and local government in
a manner that the Local government is given reasonable scope to raise
funds and to use its resources to provide a range of socio-economic
services and establish programmes to enhance the welfare of those
resident in its area of authority (Asaju 2010: 100-101).

Following from this position, it is imperative to point out that a well decentralized administrative system does not seek to establish mere subordinate units but gives corresponding authority to the units for better performance. Decentralization is a term that provides in more succinct manner the spectrum of power relations or levels of institutional power. It transfers authority to ensure the recognition of local councils as legitimate 
institution while at the same time reinforces its capacity as a problem solving grassroot government. Thus, it is believed that decentralization would make the local governments more competent in the management of their own affairs (Lawal and Oladunjoye 2010:229). Though, this position to a greater extent appears contentious, because not all decentralized systems have competently evolved managerial dexterity towards goal accomplishment. In fact, decentralization is a prerequisite element for effective and efficient management but not an adequate conditionality for local development. For instance, in Nigeria, power seems to have been transferred to lower levels of government (ie the state and local government) but this does not actually guarantee accountability, responsiveness, efficiency, transparency and has actually not given people the power to decide their fate on issues affecting them. Adam (1993) had earlier posited that decentralization processes generally do not proceed further than deconcentration processes, i.e. the extension of central institutions (cited in Tötemeyer 1999:108). For him, it remains within the context of vertical political structures and depends mainly on central decisions. However, it is pertinent to assert that the relevance of decentralized administration lies in its capacity to create units with commensurate powers towards setting priorities at the local stage and identifying local problems with discretionary power to solving them for development at the grassroot. Bonnal captures the relevance of decentralization in any polity when he observes that:

decentralization has kept its promise as far as the strengthening of democracy at the national level is concerned, as well as the central government's commitment in favour of rural development. It has thus contributed toward moving away from the bias toward urban areas in matters of development; to better management of the coordination of integrated rural development projects, and ensuring their sustainability. Decentralization has also reduced poverty which results from regional disparities, in paying more attention to the attendant socio-economic factors, in facilitating the gradual increase in development efforts and the promotion of cooperation between the government and NGOs, while increasing transparency, accountability and the response capacity of institutions (cited in Lawal and Oladunjoye 2010:230).

These values, according to Gboyega (1987:3) promote democracy; they are contributive to the development of a democratic climate. Thus, it is important to note that these imbedded attributes appear either lacking or unable to improve local government system in Nigeria since 1999. In most capitalist states especially those with federal structures such as the USA, Canada etc, there exists a kind of "decentralization that ensures that appropriate divisions of functions exist between the state and local governments and those local authorities thereby play a significant role in the development process" (Oyediran, 2001: 197). Undemocratic local councils (as presently in most states in Nigeria) cannot strengthen democracy. It seems to have exacerbated poverty incidences and aggravated development crisis in Nigeria as a result of persistent use of self accountable administrators (caretaker committee) at the local government. This is not to say that decentralization could not trigger or even promote competition, improve quality of life at the grassroot and sustainable local development. In fact, highly controlled decentralization or poorly managed decentralized administration appears perilous than a centralized system. It has the tendency of disconnecting the people from their immediate and nearest government that may serve as their training ground and life wire for further political endeavors.

On the other hand, devolution deals with power relations among levels of government. Devolution distinguishes institutions in terms of structure, power they possess, functions they perform and how they formally relate to each other. Its adoption and actual practice is conventionally and legally incorporated in the ground norms that guide every system that evolves through devolution. Though, it could be seen as a form of decentralization but its major concern is on scope of exercise of power by various levels of government. This is to ensure that each arm of government operates within the ambit of the law to avert unnecessary conflicts arising from usurpation of powers of another level of government. In his opinion, Okotie (2010:15) asserts:

Devolution is associated with local autonomy and with increase scope for popular participation in governmental activities. Under the devolution category, local governments are granted powers to source for their revenue control their finances as well as recruit their own personnel. Devolution indicates status and policy making power. Devolution of power is also designed to create a political environment in which power to access political, economical and social resources is distributed between the central government and lower levels of government. State authority is divided among a wide range of actors, making politics less threatening and therefore encouraging joint problem solving. Devolution 


\section{creates a fairer political ground, protects groups and individual human rights, establishes check and balances to central power and prevents political violence among rival groups.}

Also, Tötemeyer (1999) explains the concept as a necessity in Africa especially in the period of democratization. For him, effective devolution of power and resources from the central to the local level of government and administration, within the ongoing democratization process in Africa, was considered as a prerequisite for peace and stability in African societies and states. He further states that devolution entails recognition and a capacity of problem-solving, reconciliation, and conflict resolution at the local level, both through "traditional" methods of seeking consensus, and restructuring and balancing budgets throughout the state hierarchy (Tötemeyer 1999:113). Thus, Rondinelli (1981:139) explains devolution as a form of decentralization in which the central government retains some supervisory powers and may play a large financial role. While it is understandable the need for the central government to supervise activities of the local government to ensure accountability and conformity to general development process, the financial role appears to consistently ignite crisis between both the state or federal government and the local government. In fact, it seems obvious that the intention of many state governments in Nigeria to control monthly allocations meant for local government appears to explain why state governments in Nigeria seem to prefer caretaker committees to democratic governance. This idea runs counter-productive with the concept of devolution.

Devolution could be seen as the legal framework that gives power to local government to discharge specified duties or residual power upon formally constituted local authorities. Local governments that enjoy devolution of powers are likely to be more self reliant and to a large extent enjoy autonomy from other levels of government. Devolution helps to disperse power within a political system especially through the establishment of several units or subdivisions of government, each with some degree of independence and autonomy among them. This is essential as it precludes concentration of power; ensures healthy and fair competition among state actors, administrators and groups at different levels of government. In fact, most local government reforms in Nigeria especially the 1976 reform in particular, was actually aimed at decentralizing some functions of the government at the local areas for effective management of local resources for sustainable development. It is in this regard that Ladan (2012:3) posits that the local government system in Nigeria holds a critical role in the consolidation of democracy in the country.

Local government refers to locally elected councils whose main purposes is to provide or administer services with great degree of independence as modern circumstances allow (Wraith, 1964:15-16). For the United Nations Office for Public Administration, local government is a political subdivision of a nation or (in a federal system) state, which is constituted by law and has substantial control of local affairs, including the powers to impose taxes or to exact labour for prescribed purposes. The governing body of such as entity is elected or otherwise locally selected (cited in Ola and Tonwe 2009:4). In the same vein, Oyediran (1979:171) sees local government as the diffusion of political process on area basis, i.e. local self administration and inclusion of noble ideals of impartiality, protection of minority rights and integrity, all of which are considered essential to the evolution of a liberal democratic society. Olisa (1990:93) describes it as "a unit of government below the central, regional or state governments established by law to exercise political authority through a representative council within a defined area". Thus, beyond the essential role of bringing development closer to local people, local government provides or serves as a training ground for the people. It serves as the first stage in which individuals learn the values, political culture and participate politically in the society. And as well, it prepares people for constructive engagement of the state in general. It helps individuals to acquire deeper knowledge of the society and practices, conventions that are inherently imbedded in the system.

Following from the above, it could be asserted that democratizing local governance is unavoidably a desideratum. Indeed, the democratic participatory theory contends that local government functions to bring about democracy and to afford opportunities for political participation to the citizen as well as to educate and socialize him politically (Ola, 1984: 10). For the democratic participatory theorists, local government is superior to other levels of government since it is only at the level of the municipality that the individual can really participate in his own government and so government is truly democratic. In fact, Sharpe (1970:163) explains that it is only by participating in and learning the arts of self-government at the local level that the individual had a stake in and came to appreciate the virtues of free government at the national level.

From the foregoing, democratic participatory assumptions on the need to ensuring democratic governance at the grassroot could be appreciated. Section 7 subsection (1) of the 1999 constitution, despite its deficiencies still provides that "the system of local government by democratically elected local government councils is under this Constitution guaranteed". In recognition to this, it presupposes that state governments whom the same constitution erroneously entrusted the duty of ensuring local government existence and management should ensure that where it exists, democratic aspect of its existence would not be lacking. Experiences since the inception of civilian rule in 1999 have shown that local government in Nigeria has being operating in a reverse. The constitution is mostly being blamed for the situation to the extent that it offers ample 
opportunity to state governments to abuse the intention of law. For instance, Nwabueze (1983) as in Ugwu (2003:67), observes that the constitutional power to establish local government, define its structure, composition and functions, belong to the state governments. For him, as far as it is so, the local government is a mere state agency or a creation of the state government. However, this position does not take into cognizance of the section 7 (1) of the 1999 constitution that defines the form or type of administration that would exist at the local area as "democratically elected local government council" under the state administration. Indeed, in spite of the nebulous and inadequate nature of the constitution, it still stipulates the type of government that should exist at the local council which is presently not obtainable.

\section{Constitutional Imperative For Efficient Local Government System In Nigeria.}

Looking back on the 50 years since Nigeria's independence in 1960, it can be convincingly argued that one of the dominant themes in the post-colonial agenda of politics and policy-making is the reform of local governance (Olukoshi 2011:4). Local government system in Nigeria has undergone several stages since independence in an effort to re-positioning the council for greater efficiency. These efforts involved reforms and constitutional amendments geared towards providing the local people with a form of participatory administrative system that would be a catalyst to development and build apt democratic values for democratic survival. Thus, first major impetus was the 1976 local government reforms which seeks to create a uniform local government system throughout the federation and places the local council as a tier of government. In his opinion, Ojah (2005:56) observes that the objectives of the 1976 reform include:

\section{Bringing about even and rapid development at the local levels throughout the country. Facilitating the exercise of democratic self- government close to the local levels of our society. Encouraging initiative and leadership potentials of the local people. Mobilizing human and natural resources through the involvement of members of the public in their local development areas and to provide two-way channel of communication between the local communities and the government.}

Following from the above, it could be asserted that the acceptability of the reform is predicated not only on its uniformity of operation and existence of local government system but also on its potentials to localizing governance in Nigeria. Though, the reform did not seen to have abated plethora of problems that engulfed the local government administration in Nigeria. The local government system in Nigeria is still confronted with the challenges of corruption, poor funding, inadequate staffing, poor infrastructure, faulty electioneering system and excessive control from both state and federal governments. As a result, further reforms become unavoidably necessary. Apart from the 1976 reform, the next major tinkering with the local government structure and its functioning was the review of local government administration in 1985, otherwise known as the Dasuki Review Committee (Ladan 2012:12). According to him, the terms of references of the Committee are:

1. To evolve the most suitable mode of managing local governments within the context of the present military administration.

2. To examine the existing structures, functions and financial resources available to local governments for the performance of those functions.

3. To look into the accounts/management (staff) problem of local governments, including the standardization of the various departments of the councils.

4. To evolve a proper place for traditional authorities in local governments.

5. To propose how best to manage intergovernmental relations between federal, state, and local governments and also between local governments and ministries for Local Government Service Boards/Commissions, etc.

6. To work out manpower development schemes for all local government staff.

7. To deliberate and recommend on the matters the Committee considers relevant for the improvement of local government administration in the country.

Thus, it could be noted that the local government maintained a progressive improvement between 1976 till 1993. For instance, the 1989 Constitution introduced presidential system of governance into the local government system in Nigeria in which the councils operated with executive and the legislature (councilors) and this idea was sustained in the decree 23 of 1991 and the subsequent 1999 constitution. As a result, elections were also held in the 774 local councils in Nigeria in 1998 preparatory to the return to civilian rule in 1999.

However, it could be argued that the 1999 constitution stalled enormous progress in the development of local government system in Nigeria. Ladan (2012: 5) captures this position when he argues that the 1999 Constitution is not only a move backward to 1979 Constitution but also a total regression from the gains made by the local government system between 1989 and 1999. For instance, Section 7 (1) of the 1999 Constitution provides the system of local government by democratically elected local government council is under this Constitution 
guaranteed; and accordingly, the government of every state shall, subject to section 8 of this constitution, ensure their existence under a law which provides for the establishment, structure, composition, finance and functions of such councils.

Consequently, the sorry state of local government councils in Nigeria is rooted in poor interpretation and confusion surrounding section 7 and 8 of the 1999 constitution. For instance, the confrontation between Lagos state government and the federal government on the creation of new local councils led to the unlawful seizure of Lagos state monthly allocations at the behest of the former president Olusegun Obasanjo. It is important to note that local government councils cannot be effective under the present constitutional arrangement that frivolously ally the state and the federal government in the creation and funding of local government with the federal government possessing overwhelming and chilling constitutional powers (see section 8, (8) 5, 6, section 7, 162 of the 1999 constitution). Indeed, democracy cannot thrive in a situation where duties and responsibilities are statutorily prescribed from top levels for the local government. These prescriptions hinder local councils from performing their statutory duties, negate the principles of separation of powers and as well deny the people requisite leadership training and democratic values associated with democratic practice at the local level.

\section{Functioning Of Local Government In Nigeria: The Dilemma Of State Control.}

There are myriad of challenges confronting local government system in Nigeria. The endemic corruption that seems to have eroded the essence of government, financial dependency of the local councils and most importantly the 1999 constitution that ceded the right to control, dissolve, dismiss and institute panel of inquiry into the general administration of any local government by the states. Consequently, over the years especially since the return to democracy in 1999, the local government in Nigeria exists at the mercy of the state governments in the manner that frustrates or ridicules their existence. The tendency of usurping the functions of the local governments had earlier been envisaged and was given considerable attention in the 1976 reform. According to the local government reform of 1976:

\section{Local governments have over the years suffered from the continued whittling down of their powers, and state governments had continued to encroach upon what would normally have been the exclusive preserves of local governments and consequently there has been a divorce between the people and government at their most basic levels (cited in Ekpo and Ndebbio 1998:1).}

However, the flaws in the 1999 constitution seem to have augmented the tempo of abuse of the local government system as well as the constitution itself. Political actors in the state and most commentators unabatedly celebrate sections of the constitution that legitimize state control without or with less emphasis on the section that defines the form of government that would exist under the control. Thus, in spite of its inadequacies, section 7 (6) of the 1999 constitution provides that a "democratically elected local government council is under this constitution guaranteed". Indeed, the reality of existence is that there is no presence of legislative organ in most local government in Nigeria, 23 out of 36 states run their local government with caretaker committees appointed by state governors (Kehinde 2012:1). The implication is severe. First, it has completely gnarled democratic structures at the local level, denied the people democratic training through participation and the forfeiture of transparency and accountability hence the absence of legislative arm does not provide opportunity for checks and balances. In such condition, financial recklessness, misappropriation and corruption would remain high.

Paradoxically, state governors who persistently confront the federal government on resource control and devolution of powers are major proponents of centralization at the state level. The governors' unveiled desperation towards managing local government finance and controlling everything concerning the local government speak volume of their preference to caretaker committee system. It is obvious that the present under-developed condition of local government in Nigeria is not mainly from constitutional shortcomings rather the unchecked and unrestrained desire of the state to abuse constitutional privileges. The inordinate drive to dictate the type of administration against constitutional stipulation is critical in understanding the woes of local government in the fourth republic.

The foregoing explains why people have become so disconnected and alienated from the supposedly nearest government created to train and better the lots of the people at the grassroot. It is evidently clear that governors of many states in Nigeria have doubled their mandate. The governors' excessive and invidious control of local government tends to have engendered a frosty intercourse between the grassroot people and the local government administration, enhances corruption among the governors, caretaker committees and political collaborators. In such situation, the tendency of odious relationship that may stultify development progress at the local level and as well challenges democratic survival in the country generally seems possible. Indeed, local government must be liberated from governors who have added local government to their official mandate. The 
present trend is antithetical to the basic principles of democracy and to a greater extent denies the people values associated with democratic practices.

\section{Conclusion.}

From our analysis, it is obvious that in spite of numerous efforts at salvaging the local government system in Nigeria, the local government council is still very far from sighting the promise land. This is as a result of overzealousness of state governments to control and unrestrained drive in their abuse of constitutional privileges. While we are not oblivious of constitutional shortcomings that have blurred and stagnated progress, it is our submission that there is no perfect constitution. Hence, the present condition of the local governments in Nigeria is elite (specifically governors) inflicted. While we also advocate for the amendment of relevant provisions of 1999 constitution that surrendered the control of local government in the hands of state especially in the present amendment, it is our view that the emergence of new constitution devoid of such clauses may not guarantee development at the grassroot if political leaders do not refrain from reckless abuse of the law of the land.

\section{References}

[1] O. Ezeani, Local government administration (Enugu, Zic-Chuks Printing Press, 2004).

[2] A. Olukoshi, Building democratic local governance in Nigeria: The imperatives. Being a paper delivered at the Wole Soyinka centre, as part of activities to commemorate the 77th birthday of Professor Wole Soyinka, Lagos, 2011, 1-11.

[3] O. Ojah, Trends, problems and prospects of effective public administration in Nigeria (Calabar, Nigerian Images, 2005).

[4] A. Gboyega, Political values and local government in Nigeria (Lagos, Malthouse Press Ltd, 1987).

[5] A. Mokoro, Evolution of a democratic local government system in Nigeria, Kama-Raj Journal of Social Science, 7 (3), 2003, 170179 .

[6] O. Ikeanyibe, Local government and constitutional elasticity, in S. Odion-Akhaine (Ed.), Local Government Administration in Nigeria, Old and New Vision (Lagos: Centre for Constitutionalism and Demilitarization 2009) 22-43.

[7] S. Omotola, Local government reform under the fourth republic, in S. Odion-Akhaine (Ed.) Local Government Administration in Nigeria, Old and New Vision (Lagos: Centre for Constitutionalism and Demilitarization 2009) 142-160.

[8] C. J. Nwanegbo, Local government and intergovernmental relations under Nigerian federalism, in J. Onuoha and C. J. Nwanegbo (Eds.) Theory and Practice of Intergovernmental Relations in Nigeria (Enugu: Quintagon 2007) 121-134.

[9] C. J. Nwanegbo and P. Chikendu, Local government autonomy under true federalism in Nigeria, American Journal of International Politics and Development Studies, 1 (1), 2005, 177-189.

[10] C. J. Nwanegbo, and U. Okafor. The constitutionality of the creation of local government by some states vis-à-vis the power of the national assembly in Nigeria, African Journal of Political and Administrative Studies, 2 (1) 2005, 315-330.

[11] A. Adedokun, The development of local government in Nigeria since pre-colonial era to 1999 constitution Polycom, 2, (2) 2004, 117 .

[12] D. Rondinelli, government decentralization in developing countries, International Review of Administration Science, XL VII, (2) $1981,135-146$

[13] G. Totemeyer, Decentralization and State-Building at the Local Level, A Paper presented at the University of Namibia, Windhoek, 1999, 108-149.

[14] K. Asaju, Local lovernment autonomy in Nigeria: politics and challenges of the 1999 constitution, International Journal of Advanced Legal Studies and Governance 1 (1), 2010, 98-113.

[15] T. Lawal and A. Oladunjoye, Local government, corruption and democracy in Nigeria, Journal of Sustainable Development in Africa, 12 (5) 2010, 227-235.

[16] O. Oyediran, Local government as a third tier of government in Nigeria: the1976 local government reforms and after, in J. Elaigwu, and R. Akindele, (Eds), Foundations of Nigerian Federalism, 1960-1995, (Jos: institute of governance and Social Research 2001) 194-211.

[17] H. Okotie, Evolution of nigerian local government (Lagos, National Open University of Nigeria 2010).

[18] M. Ladan, The functioning of the local government system in a federalist constitution: controversies, comparisons and consensus. $A$ paper presented at the $13^{\text {th }}$ anniversary and extra-ordinary general assembly, national conference on rediscovering the nigerian local government system in the emerging constitution, Enugu, 2012, 1-39.

[19] R. Wraith, Local administration in west africa (London, Allen and Urwin, 1964).

[20] R. Ola, and D. Tonwe, Local administration and local government in nigeria (Lagos, Amfitop Books, 2009).

[21] O. Oyediran, Nigerian government and politics under military rule: 1966-1979 (London, Macmillan Press, 1979).

[22] M. Olisa, Government for senior secondary schools (Onitsha, Africana Publishers, 1990).

[23] R. Ola, Local administration in nigeria (London, Kegan Paul International, 1984).

[24] P. Sharpe, Theories and values of local government. Political Studies, 18 (9),

[25] FGN, The 1999 constitution of the federal republic of nigeria (Abuja, Government Press, 1999).

[26] S. Ugwu, Issues in local government and urban administration in nigeria (Enugu, Academic Publishing Company, 2001).

[27] A. Ekpo and J. Ndebbio, Local government fiscal operations in nigeria (Nairobi, African Economic Research Consortium, 1998)

[28] B. Kehinde, Absence of legislative arm in local government dire to grassroot democracy, Legislative Digest, 6 (10) $2012,1-3$. 